\title{
The Influence of Drying Temperature on the Hygroscopicity of Rubberwood (Hevea Brasiliensis)
}

\author{
Hueishing Sik (Corresponding author) \& Khengten Choo \\ Forest Products Division, Forest Research Institute Malaysia \\ Kepong, 52109 Selangor Darul Ehsan, Malaysia \\ Tel: 60-3-6279-7402Ｅ-mail: sik@frim.gov.my \\ Sarani Zakaria, Sahrim Ahmad, Maisarah Yusoff \& Chinhua Chia \\ Faculty of Science and Technology, Universiti Kebangsaan Malaysia \\ 43600 Bangi, Selangor Darul Ehsan, Malaysia \\ Tel: 6-03-8921-3261Ｅ-mail: sarani@ukm.my
}

This research is funded by the Ministry of Science, Technology and Innovations, Malaysia.

\begin{abstract}
The influence of drying temperature on the hysteresis effect of rubberwood is determined in this study. Results showed reductions in sorption capacity of rubberwood dried at high temperatures as compared to the control conventional temperature dried material at respective corresponding set conditions. The reduction of the hygroscopicity of rubberwood is a combined effect of both physical, morphological structure and chemical composition as affected by the drying temperature. This improvement is found to be primarily attributed to the (i) hysteresis effect enhanced by increased drying temperature, (ii) loss of hygroscopic hemicelluloses, and (iii) rearrangement/ degradation of amorphous cellulose content in the cell wall.
\end{abstract}

Keywords: High temperature drying, Relative humidity, Sorption, Dimensional stability, Hysteresis, X-ray diffraction analysis

\section{Introduction}

Hevea brasiliensis or rubber trees of Euphorbiaceae family were introduced into Malaysia more than a century ago. Currently, it is of economic importance to the wood-based furniture manufacturing sector. Malaysia timber industry has been for more than two decades, a major export earner, of which more than $70 \%$ of the furniture exported is derived from this important and yet sustainable resource material.

Wood is often subjected to treatments at elevated temperatures in many kinds of processing activities such as drying, pulping, production of wood composites and etc. The extent of the effect of temperature on the physical, structural and chemical properties of wood depends on time of treatment, atmosphere, pressure, water content and state of distribution (Fengel and Wegener 1989). Drying is an important process in the manufacturing of wooden products such as joinery and furniture components where minimum warping, low drying stress and uniform moisture distribution are required. An effective drying practice will render suitable kiln-dried material for further processing into quality end-products, which in turns give minimum or negligible problem that may arise during service. According to Choo and Hashim (1994), rubberwood is a relatively fast drying lumber. It is reported that boards of $25 \mathrm{~mm}$ thickness take approximately 6-8 days to dry to $8-10 \%$ from an initial green moisture content of about $60 \%$. Final dry bulb temperature (DBT) setting for rubberwood drying is approximately $65.5^{\circ} \mathrm{C}$ for rubberwood of less than $50 \mathrm{~mm}$ thickness (Choo and Hashim 1994).

Generally, wood is a hygroscopic material which will readily takes up moisture and swells when exposed to a wetter condition, or expels moisture and shrinks into a smaller dimension when subjected to a condition of lower humidity until equilibrium is reached. The dimensional stability properties of a particular wood are important to reduce incidences of undesirable or excessive 'movement' which, could results in severe warping in finished product during service. The dimensional stability of wood can be enhanced through wood modification, involving either the chemical reaction through heat treatment or chemical treatment (Rowell 2004). Chemical modifications in wood structure 
occurring at high temperature has improved several physical structures resulting in reduced shrinkage and swelling, low equilibrium moisture content, enhanced weather resistance, better decay resistance and etc (Yildiz and Gumuskaya 2007).

The application of drying method also influences the dimensional stability of wood (Bekhta and Niemz 2003). Drying at high temperature tends to lower the equilibrium moisture content of wood. Drying at high temperature is accomplished at dry-bulb temperatures of $100^{\circ} \mathrm{C}$ or higher, usually from $110^{\circ} \mathrm{C}$ to $121^{\circ} \mathrm{C}$ (Boone 1983). This drying regime has been mentioned as a time and cost saving processing practice in view of the escalating cost of production in the wood-based manufacturing sector. High Temperature (HT) drying of softwoods such as plantation grown radiata pine and other southern pines has long been practised in countries like Australia, New Zealand and in the United States. However, HT drying of tropical hardwoods is still unknown in Malaysia and other tropical hardwoods producing regions. Dehumidification system and steam-heated, forced-air drying system (conventional kiln) are used in Peninsular Malaysia to dry rubberwood, with the latter being the more preferred system (Anonymous 1982) and still accounts for more than $90 \%$ of the kiln drying practice in the country. The high temperature regime had been mentioned as a tool in reducing drying time, resulting in lower inventory costs and smaller plant sites (Milota 2000). The application of high temperatures in artificial drying greatly reduces the sorption capacity of wood (Kollmann and Schneider 1963) and hence, wood that has been exposed to high temperatures is less hygroscopic (Kininmonth 1976).

Sorption consists of both adsorption and desorption processes. When wood attained its equilibrium moisture content $(\mathrm{EMC})$ at any given relative humidity $(\mathrm{RH})$ from a higher or lower $\mathrm{RH}$, the adsorption and desorption isotherms form a "loop" and the difference in moisture content is call hysteresis (Kollmann and Cote 1984). Adsorption involves the attraction of water molecules to hydrogen bonding sites present in cellulose, hemicellulose and lignin. According to Hirai et al. (1972), the crystallinity of wood cellulose, when heated increases initially and decreases as the heating time extended. The increased of the width of cellulose crystallite and crystallinity during the initial stage of heating in the range of $120-160^{\circ} \mathrm{C}$ was observed and then remained constant (Hill 2006), while decrease of crystallinity after $160^{\circ} \mathrm{C}$ was reported (Roffael and Schaller 1971). Increase in crystallisation could be due to the loss of hemicellulose, the most hygroscopic component of the wood (Hill 2006).

In this study, the sorption hysteresis of rubberwood dried at high temperatures is compared to the control samples dried at conventional temperature. Besides, its relation to the cellulose crystallinity and hemicellulose content will be investigated.

\section{Materials and Methods}

\subsection{Drying Procedure}

Rubberwood logs from 25-30 year-old rubber trees of RRIM 600 clone were obtained for this study. Sawn furniture dimensional stock of $30 \mathrm{~mm}(\mathrm{~T})$ x $100 \mathrm{~mm}(\mathrm{~W})$ x $600 \mathrm{~mm}(\mathrm{~L})$ were prepared for the HT drying runs at dry bulb temperatures (DBTs) of $100^{\circ} \mathrm{C}, 120^{\circ} \mathrm{C}, 130^{\circ} \mathrm{C}, 140^{\circ} \mathrm{C}$ and $150^{\circ} \mathrm{C}$. While the DBT for control conventional drying run was set at $60^{\circ} \mathrm{C}$. The drying runs were conducted in a laboratory experimental kiln and the respective DBT settings were maintained throughout each experiment. All test pieces were dried from the green condition (with initial moisture content at an average of 68\%) until the average moisture content for each drying run was reduced down to approximately $6 \%$ based on estimated oven-dried weight.

\subsection{Sorption hysteresis study}

After drying, the rubberwood specimens were fine dressed to a thickness of $3 \mathrm{~mm}$ and cut to a standard length of $50 \mathrm{~mm}$ and width of 100mm (Figure 1). The specimens were then exposed to a series of seven sets of EMC conditions (Table 1) in a Tabai Espec Corp. Temperature and Humidity Chamber (model SH 641), with constant humidity-temperature settings as tabulated. The exposure tests were conducted in two stages, i.e. the first stage investigated the adsorption behaviour of dried samples at a series of set EMC conditions from $8 \%$ to $20 \%$ EMC. Whereas, the second stage assessed the desorption behaviour of the dried samples from 20\% EMC down to 8\% EMC condition. During each respective EMC step, the individual samples will be weighed periodically until constant weight is achieved, before proceeding to the next set condition. At the end of testing, the test specimens were oven-dried at $103 \pm 2{ }^{\circ} \mathrm{C}$ for calculation of the EMC [equation 1] of the rubberwood attained at respective EMC conditions. Moisture exclusion efficiency (MEE) [equation 2] of rubberwood treated at high temperatures is calculated based on the EMC obtained by the control samples.

$$
\text { EMC }(\%) \text { attained }=\left[\left(\mathrm{M}_{\mathrm{b}}-\mathrm{M}_{\mathrm{a}}\right) / \mathrm{M}_{\mathrm{a}} \times 100 \%\right.
$$

Where,

$\mathrm{EMC}=$ Equilibrium moisture content attained by rubberwood

$\mathrm{M}_{\mathrm{a}}=$ Oven dry weight 
$\mathrm{M}_{\mathrm{b}}=$ Weight attained at equilibrium

$\operatorname{MEE} \frac{(\%)=\mathrm{MC}(\text { control })-\mathrm{MC}(\text { High temperature dried }) \times 100 \%}{\mathrm{MC}(\text { control })}$

Where,

MEE $=$ Moisture exclusion efficiency

$\mathrm{MC}=$ Moisture content of wood

$2.3 \mathrm{X}$-ray diffraction analysis

Specimens for X-ray diffraction (XRD) analysis were obtained from the same matched sample (Figure 1) board used for hygroscopic study. XRD specimens of $20 \mathrm{~mm}$ x $20 \mathrm{~mm}$ wide measured at $2 \mathrm{~mm}$ thickness at two different layers acquired from each dried test samples. The first layer (L1) was measured from the wood surface to $2 \mathrm{~mm}$ deep into the specimen and the second layer (L2) was obtained at another $2 \mathrm{~mm}$ deep adjacent to the first layer (Figure 1). The crystallite size of cellulose was estimated from the full width at half maximum (FWHM) according to the Scherrer equation [equation 3].

$$
\mathrm{D}=0.9 \lambda /\left(\beta_{1 / 2} \cos \theta\right)
$$

where $D$ is the crystallite size; $\lambda$ is the X-ray wavelength; $\beta_{1 / 2}$ is the angular width at half maximum intensity of the diffraction peak; $\theta$ is the angular position of the diffraction peak.

\subsection{Analysis of holocellulose and alpha-cellulose content}

Determination of holocellulose content of rubberwood after drying at respective temperatures was based on analytical method for pulp chemistry by Wise et al. (1946). The alpha-cellulose content was determined based on TAPPI standard methods (TAPPI T 203 os-74 1994).

\section{Results and discussions}

\subsection{Sorption hysteresis of rubberwood}

The mean EMC values of rubberwood dried respectively at control conventional and high temperatures after achieving equilibration with respective set EMC conditions in both adsorption and desorption processes, are presented in respective error bar charts at 95\% confidence level (Figure 2.1-7 and Figure 3.1-7). The EMC values were calculated using equation (1).

Generally, the reductions in sorption capacity of rubberwood dried at high temperatures as compared to the control conventional temperature dried material were observed during adsorption process (Figure 2.1-7) and desorption process (Figure 3.1-7) in the sorption study. Several researchers reported that HT dried wood is less hygroscopic (Espenas 1971; Price and Koch 1980), with lower EMC value compared to wood which has been dried using conventional method (Calvert 1958). Hygroscopicity of wood decreases as degree of thermal degradation increases was reported (Seborg et al. 1953)

ANOVA has been performed to test the significance of the overall experimental effect, i.e. temperature effect in this case study, though it is unable to show which treatment groups differed. Hence, in addition to ANOVA, Post Hoc Test (PHT) which is based on pairwise comparisons that are designed to compare all different combinations of the treatment groups (Field 2000) is carried out.

Analysis of variance (ANOVA) showed that the overall experimental effect was highly significant $(\mathrm{P}<0.001)$ for mean values of all temperature groups against the various set EMC conditions during both sorption processes, except for mean values attained at $8 \%$ EMC condition during desorption process (Figure 3.1) with significant level, $\mathrm{P}>0.05$ at $95 \%$ confidence level. PHT showed that EMC values of control samples $\left(60^{\circ} \mathrm{C}\right)$ attained at $8 \%, 10 \%, 12 \%, 14 \%$ and $16 \%$ EMC condition during adsorption are significant $(\mathrm{P}<0.01)$ compared to respective HT groups. While at $18 \%$ and $20 \%$ EMC condition during adsorption, the control samples showed significant differences $(\mathrm{P}<0.05)$ compared to all HT groups except for $100^{\circ} \mathrm{C}$-dried samples. On the other hand, ANOVA showed that the temperature effect on EMC values attained during desorption at $8 \%$ EMC condition are not significant at $95 \%$ confidence level for all temperature groups. Nonetheless, PHT showed that at higher humidity range from $49 \%$ to $90 \%$, the EMC values of control samples are significant compared to all HT treatment groups except for $100^{\circ} \mathrm{C}$-dried samples during desorption at $10 \%$ EMC condition.

PHT showed that temperature treatment affected the adsorption and desorption behaviour of rubberwood differently especially among the HT treatment groups. The reduction in hygroscopicity of rubberwood was enhanced as the drying temperature increases. In addition, rubberwood dried at $130^{\circ} \mathrm{C}$ have generally equilibrated with the lowest EMC over the relative humidity range $\left(37 \%\right.$ to $\left.90 \% @ 30^{\circ} \mathrm{C}\right)$ tested during adsorption, while it attained the lowest EMC except at $8 \%$ and $16 \%$ EMC conditions during desorption compared to the rest of the drying runs. PHT showed that these 
reductions as observed in $130^{\circ} \mathrm{C}$ rubberwood are significant compared to control, $100^{\circ}, 120^{\circ} \mathrm{C}$ and $140^{\circ} \mathrm{C}$ over the relative humidity range of $37 \%$ to $68 \%$ during adsorption process. Whereas, reductions in adsorption recorded in $130^{\circ} \mathrm{C}$-dried rubberwood over the higher relative humidity range of $77 \%$ to $90 \%$ are significant $(\mathrm{P}<0.05)$ compared to the control, $100^{\circ} \mathrm{C}$ and $120^{\circ} \mathrm{C}$-dried samples. This distinct finding will be further discussed under the of X-ray diffraction and holocellulose content analysis. Generally, the reductions of desorption capacity are not significantly different between the HT treatment groups at least up to $150^{\circ} \mathrm{C}\left(100^{\circ} \mathrm{C}-150^{\circ} \mathrm{C}\right)$. PHT showed The EMC values did not differ significantly $(\mathrm{P}>0.05)$ between $120^{\circ} \mathrm{C}, 130^{\circ} \mathrm{C}, 140^{\circ} \mathrm{C}$ and $150^{\circ} \mathrm{C}$ - dried samples during desorption at $12 \%, 14 \%$, $16 \%$ and $20 \%$ EMC conditions. Whereas, the EMC values as indicated by PHT, did not differ significantly (P>0.05) between $120^{\circ} \mathrm{C}, 130^{\circ} \mathrm{C}$ and $140^{\circ} \mathrm{C}$ - dried samples during desorption at $10 \%$ and $18 \%$ EMC conditions. Overall, the differences in hygroscopicity due to HT treatment were more distinct during adsorption as compared to the desorption process of rubberwood, similar to an earlier observation during heat treatment of hardwood species as reported by Chang and Keith (1978).

The EMC values attained during adsorption are comparatively lower than the desorption process at corresponding set EMC conditions. This trend agrees with the general observation of hysteresis effect recorded during the adsorption and desorption of various materials including wood. This effect may have been accentuated by the increased temperatures employed in the study as reflected by the relatively lower EMCs attained by rubberwood samples dried at high temperatures compared to the conventional temperature dried material(Figure 2.1-7 and Figure 3.1-7).

The reduction in EMC as a result of wood modification has been reported in terms of a parameter referred to as the moisture exclusion efficiency (MEE) (Hill 2006). The dimensional stabilisation through temperature treatment can be gauged using the MEE based on equation (2). The MEE (\%) of HT dried samples were presented in Table 2. In this study, the positive MEE values attained has indicated that the HT drying is effective in reducing the sorption capacity of rubberwood. For a specific humidity, MEE values generally increase for rubberwood which were subjected to higher temperature during adsorption process. This indicates that the HT drying is much more effective at reducing the moisture uptakes of rubberwood at all humidity levels.

\subsection{X-ray diffraction and holocellulose content analysis}

The X-ray diffractograms for the rubberwood dried at control conventional and high temperatures are shown in Figure 4.

A typical type I cellulose pattern with 002 peaks at $2 \theta$ of the diffractograms showed that the respective 002 peaks recorded in dried rubberwoods obtained from L1 layer of various drying temperatures remained in the same vertical alignment at the angular position of the peak. In addition, an increase of the sharpness of 002 peak can be observed as the drying temperature increased from control conventional temperature of $60^{\circ} \mathrm{C}$ to $130^{\circ} \mathrm{C}$, and followed by a decrease after $130^{\circ} \mathrm{C}$. These findings are also reflected by the mean crystallite size determined for rubberwood obtained at $\mathrm{L} 1$ and L2 layers that were dried at various temperatures as shown in Figure 5. In general, the cellulose crystallite size of L1 layers from various drying treatment temperatures was slightly higher than those of L2 layers due to a more intense temperature effect caused by direct heat contact. Moreover, the relatively small value deviations between the crystallite size determined at L1 and L2 layers indicated that the effect of temperature on the crystallinity of rubberwood are not just superficial, as the enhancement of the morphology properties of rubberwood can be observed at least up to $4 \mathrm{~mm}$ deep into the L2 layer of the wood (Figure 5).

The increase in peak heights as shown in Figure 4 indicates increase in crystallisation. Increase in crystallisation could be attributed to loss of hemicelluloses and degradation/ rearrangement of amorphous cellulose content (Hill 2006). Therefore, the highest reduction in sorption capacity as observed in $130^{\circ} \mathrm{C}$-dried rubberwood (Figure 2.1-7 and 3.1-7) could be explained by its improved crystallinity, resulting in fewer hydrogen bonding sites as compared to other levels of temperature treatments employed in the study. According to Tjeerdsma et al. (1998), significant reduction in water adsorption of heat-treated wood could be attributed to the increase in the relative proportion of the crystalline cellulose, in which the hydroxyl groups are not easily accessible to water molecules.

Figure 6 showed the holocellulose (alpha-cellulose and hemicellulose) content of rubberwood dried at control conventional and high temperatures. The holocellulose content of all samples were not affected by the high temperatures which showed that rubberwood were quite thermally stable at least up to $150^{\circ} \mathrm{C}$. However, a slight decrease of hemicelluloses content of rubberwood was observed as treatment temperature increased from $120^{\circ} \mathrm{C}$ to $150^{\circ} \mathrm{C}$. In high temperature dried material, Hinterstoisser et al. (1992) found an increase of hot water extractible carbohydrates that contained monosaccharides which served as units for the hemicelluloses, and was subsequently inferred by her as a decomposition of hemicelluloses. Due to their generally amorphous nature, hemicelluloses are non-crystalline, highly branched heteropolysaccharides (Sjöeström 1981; Fengel and Wegener 1984) and they contain the greatest proportion of accessible $\mathrm{OH}$ content of the cell wall and are less thermally stable than cellulose or lignin (Hill 2006). 
Decomposition of the hemicelluloses, which is the most hygroscopic component in wood (Hill 2006) and/or coupled with the enhanced hysteresis effect after drying at high temperatures, could be the main reason for the decrease in moisture uptake of rubberwood dried at $140^{\circ} \mathrm{C}$ and $150^{\circ} \mathrm{C}$ despite a slight decrease of crystallinity/ mean crystallite size (Figure 4 and 5) compared to $130^{\circ} \mathrm{C}$. Lower higroscopicity of heat-treated wood is attributed to the irreversible structural changes of wood constutuents, such as the loss and chemical changes of hygroscopic hemicelluloses (Mitchell et al. 1953). On the other hand, conventional temperature and $100^{\circ} \mathrm{C}$ dried rubberwood showed lower holocellulose content compared to those obtained at higher temperatures, which could be attributed to the longer exposure treatment time required to dry the timber down to the targeted MC. Treatment time has been reported as one of the important factors that influences the magnitude of the temperature effect on the physical, structural and chemical properties of wood (Fengel and Wegener 1989).

According to Obataya et al. (2002), the modification of lignin and of the lignin carbohydrate complex during the heat treatment of wood is responsible for the irreversible reduction of wood hygroscopic. Repellin and Guyonnet (2005) also suggested that structural modifications and chemical changes of lignin also play an important role in reduction of wood hygroscopicity besides the disappearance of hemicellulose adsorption sites that accompanies hemicellulose destruction. Hence, the findings of this paper will be enhanced with further study in relation to the chemical components changes aforementioned due to the influence of drying temperature.

\section{Conclusions}

The application of high temperature drying is found to be able to reduce the hygroscopicity of rubberwood compared to the conventional temperature dried material. Results showed reductions in sorption capacity of rubberwood dried at high temperatures as compared to the control conventional temperature dried material at respective corresponding set conditions. During both sorption processes, rubberwood dried at $130^{\circ} \mathrm{C}$ have equilibrated with the lowest EMC over the relative humidity range $\left(37 \%\right.$ to $\left.90 \% @ 30^{\circ} \mathrm{C}\right)$ tested. These findings are explained by X-ray diffraction analysis, where an increase of the sharpness of 002 peak of type I cellulose pattern can be observed, as the drying temperature increased from control conventional temperature of $60^{\circ} \mathrm{C}$ to $130^{\circ} \mathrm{C}$, and followed by a decrease after $130^{\circ} \mathrm{C}$. The reduction of the hygroscopicity of rubberwood is a combined effect of both physical, morphological structure and chemical composition as affected by the drying temperature. This improvement is found to be primarily attributed to the (i) hysteresis effect enhanced by increased drying temperature, changes in (ii) chemical composition i.e. loss of hygroscopic hemicelluloses, and (iii) morphological structure of the wood caused by rearrangement/ degradation of amorphous cellulose content in the cell wall, which led to the reduction in sorption capacity, hence better wood dimensional stability is expected.

\section{References}

Anonymous. (1982). Malaysian Timbers - Rubberwood. Timber Trade Leaflet No. 58. Malaysian Timber Industry Board and Forest Research Institute Malaysia. pp 12.

Bekhta, P., \& Niemz, P. (2003). Effect of high temperature on the change in color, dimensional stability and mechanical properties of spruce wood. Holzforschung, 57(5): 539-546.

Boone, R.S. (1983). High-temperature kiln-drying of 4/4 lumber from 12 hardwood species. Forest Products J., 34(3): $10-18$.

Calvert, W.W. (1958). High temperature kiln-drying of lumber- a summary of Canadian progress. Forest Product J., 200-204.

Chang, C.I., \& Keith, C.T. (1978). Properties of heat-darkened wood. II - mechanical properties and gluability. Ottawa: Eastern Forest Products Laboratory. Fisheries and Environment. Canada, 1-19.

Choo, K.T. \& Hashim, W.S. (1994). Seasoning of rubberwood. Pp. 105-119 Hong, L.T. and Sim, H.C. (Eds.)

Rubberwood Processing and Utilization. Forest Research Institute Malaysia, Kepong.

Espenas, L.D. (1971). Shrinkage of Douglas-fir, western hemlock and red alder as affected by drying conditions. Forest Prod. J., 21(6): $44-46$.

Fengel, D., \& Wegener, G. (1989). Wood: Chemistry, Ultrastructure, Reactions. De Gruyter, Berlin, (Chapter 5 and 12).

Field, A. (2000). Discovering Statistic Using SPSS for Windows. Sage Publications Ltd., London, (Chapter 6 and Chapter 7).

Hill, Callum A.S. (2006). Wood Modification: Chemical, Thermal and Other Process. John Wiley and Sons Ltd., Chichester, (Chapter 5).

Hinterstoisser, B., Weingärtner, J., \& Praznik, W. (1992). Influence of wood drying processes on the carbohydrate matrix of wood of Picea Abies. In Proceedings of $3^{\text {rd }}$ IUFRO International Wood Drying Conference, Vienna, Austria, August 18-21, 217-221. 
Hirai, N., Sobue, N., \& Asano, I. (1972). Studies of piezoelectric effect of wood. IV. Effects of heat treatment on cellulose crystallites and piezoelectric of wood. Mokuzai Gakkaishi, 18: 535-542.

Kininmonth, J.A. (1976). Effect of timber drying temperature on subsequent moisture and dimensional changes. New Zealand Journal Forestry Science, 6(1):101-107.

Kollmann, F., \& Schneider, A. (1963). Über das Sortionsverhalten wärmebehandelter Hölzer. Holz als Roh- und Werkstoff, 21: 77-85.

Kollmann, F.F.P. \& Cote, Jr., W.A. (1984). Principles of Wood Science and Technology- Volume I: Solid Wood. Springer-Verlag Berlin, Heidelberg, New York, Tokyo, (Chapter 6).

Milota, M.R. (2000). Warp and shrinkage of hem-fir stud lumber dried at conventional and high temperatures. Forest Products Journal, 50(11/12): 79-84.

Mitchell, R.L. Seborg, R.M. \& Millet, M.A. (1953). Effect of heat on the properties and chemical composition of Douglas-fir wood and its major components. Journal of Forest Product Research Society, 3:38-42.

Obataya, E., Higashihara, T. \& Tomita, B. (2002). Hygroscopicity of heat-treated wood III- Effect of steaming on the hygroscopicity of wood. Mokuzai Gakkaishi, 48(5):348-355.

Price, E.W. \& Koch, P. (1980). Kiln time and temperature affect shrinkage, warp and mechanical properties of Southern Pine lumber. Forest Products Journal, 30(8): 41-47.

Repellin, V. \& Guyonnet R. (2005). Evaluation of heat-treated wood swelling by differential scanning calorimetry in relation to chemical composition. Holzforchung, 59:28-34.

Roffael, E., \& Schaller, K. (1971). The influence of thermal treatment on cellulose. Holz als Roh-und Werkstoff, 29: 275-278.

Rowell, R.M. (2004). Chemical modification. Solid Wood Processing. Elsevier Ltd. 1269-1274.

Seborg, R.M., Tarkow, H. \& Stamm, A.J. (1953). Effect of heat upon the dimensional stabilization of wood. Journal of Forest Product Research Society, 3:59-67.

Sjöeström, E. (1981). Wood Chemistry Fundamentals and Applications. Academic Press, New York, (Chapter 3).

TAPPI (Technical Association of Pulp and Paper Industry) Test Methods. (1994). Alpha-, Beta-, and Gamma-Cellulose in Pulp. T 203 os-74. TAPPI Press, Atlanta, Georgia.

Tjeerdsma, B.F. \& Militz, H. (1998). Characterization of thermally modified wood: molecular reasons for wood performance improvement. Holz als Roh-und Werkstoff, 56:149-153.

Wise, L.D., Murphy, M., \& D’Addieco, A. A. (1946). Chlorite holocellulose: Its fractionation and bearing on summative wood analysis and on studies on hemicellulose. Paper Trade Journal, 122(2):35-43.

Yildiz, S., \& Gumuskaya, E. (2007). The effects of thermal modification on crystalline structure of cellulose in soft and hardwood. Building and Environment, 42: 62-67.

Table 1. Equilibrium moisture content (EMC) settings

\begin{tabular}{cc}
\hline${ }^{*}$ Relative Humidity @ $30^{\circ} \mathrm{C}$ & Set EMC Condition (\%) \\
\hline 37 & 8 \\
49 & 10 \\
60 & 12 \\
68 & 14 \\
77 & 16 \\
83 & 18 \\
90 & 20 \\
\hline
\end{tabular}

Note: *The EMC settings were based on the EMC curves for wood established by Building Research Establishment, Princes Risborough Laboratory and published by Timber Research and Development Association (TRADA). 
Table 2. Moisture exclusion efficiency, MEE (\%) of high temperature dried rubberwood

\begin{tabular}{|c|c|c|c|c|c|c|c|}
\hline \multirow[b]{2}{*}{ Adsorption Process ${ }^{*}$} & \multicolumn{7}{|c|}{ Relative Humidity (\%) } \\
\hline & 37 & 49 & 60 & 68 & 77 & 83 & 90 \\
\hline Drying Temperature $\left({ }^{\circ} \mathrm{C}\right)$ & \multicolumn{7}{|c|}{ Moisture Exclusion Efficiency (\%) } \\
\hline $100{ }^{\circ} \mathrm{C}$ & 11.8 & 10.1 & 9.6 & 7.1 & 4.7 & 4.1 & 2.4 \\
\hline $120^{\circ} \mathrm{C}$ & 16.8 & 16.4 & 15.5 & 12.5 & 6.1 & 6.1 & 3.6 \\
\hline $130{ }^{\circ} \mathrm{C}$ & 26.2 & 24.1 & 22.0 & 19.0 & 16.4 & 16.7 & 12.6 \\
\hline $140{ }^{\circ} \mathrm{C}$ & 21.5 & 15.0 & 13.9 & 12.3 & 12.0 & 10.2 & 9.5 \\
\hline \multirow[t]{2}{*}{$150 \quad{ }^{\circ} \mathrm{C}$} & 24.8 & 21.1 & 17.8 & 14.7 & 12.9 & 10.8 & 9.9 \\
\hline & \multicolumn{7}{|c|}{ Relative Humidity (\%) } \\
\hline Desorption Process ${ }^{*}$ & 90 & 83 & 77 & 68 & 60 & 49 & 37 \\
\hline Drying Temperature $\left({ }^{\circ} \mathrm{C}\right)$ & \multicolumn{7}{|c|}{ Moisture Exclusion Efficiency (\%) } \\
\hline $100{ }^{\circ} \mathrm{C}$ & 8.0 & 4.7 & 5.5 & 6.8 & 7.9 & 8.2 & 6.9 \\
\hline $120^{\circ} \mathrm{C}$ & 10.4 & 6.3 & 7.5 & 9.0 & 9.2 & 9.7 & 8.6 \\
\hline $130^{\circ} \mathrm{C}$ & 9.8 & 7.4 & 8.6 & 11.0 & 9.5 & 11.5 & 10.9 \\
\hline $140^{\circ} \mathrm{C}$ & 9.6 & 6.6 & 8.2 & 9.8 & 10.3 & 11.2 & 10.6 \\
\hline $150^{\circ} \mathrm{C}$ & 8.3 & 5.5 & 7.3 & 9.4 & 9.7 & 9.3 & 9.6 \\
\hline
\end{tabular}

Note: ${ }^{*}$ All test carried out at constant set temperature of $30^{\circ} \mathrm{C}$.

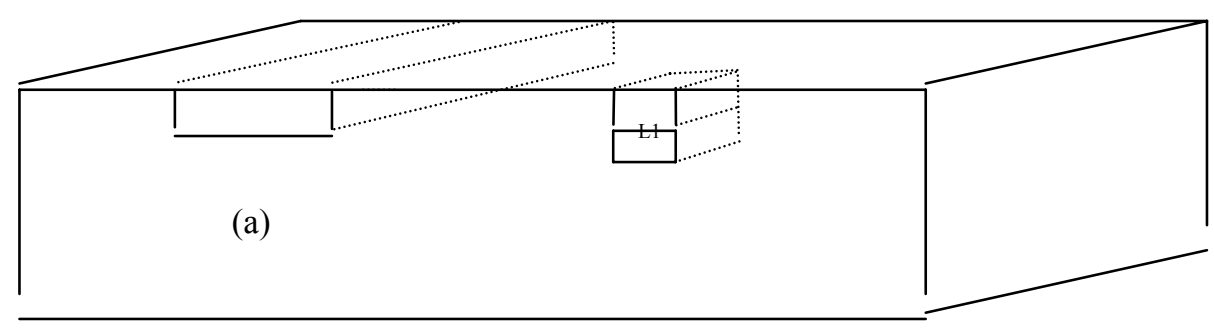

Figure 1. Sampling for analysis: Test specimens for (a) sorption study and (b) XRD analysis obtained from matched samples after drying at respective temperatures. 


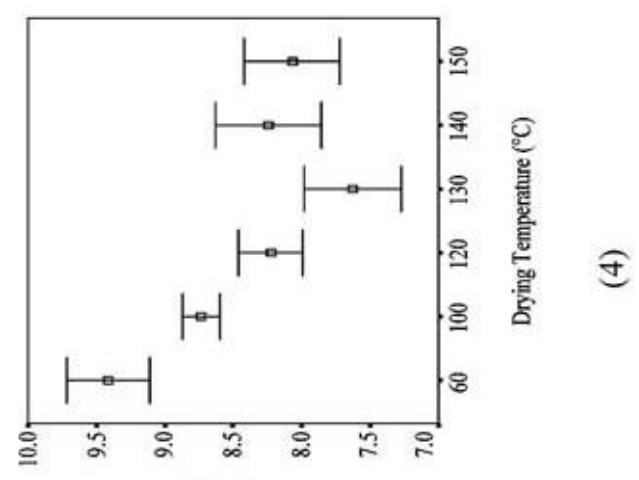

(\%) วพง

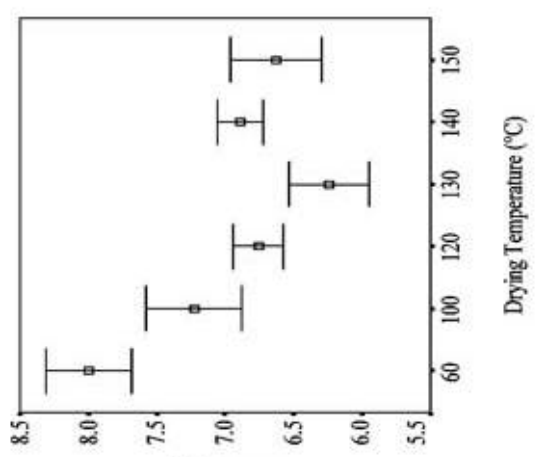

(\%) ว พ3

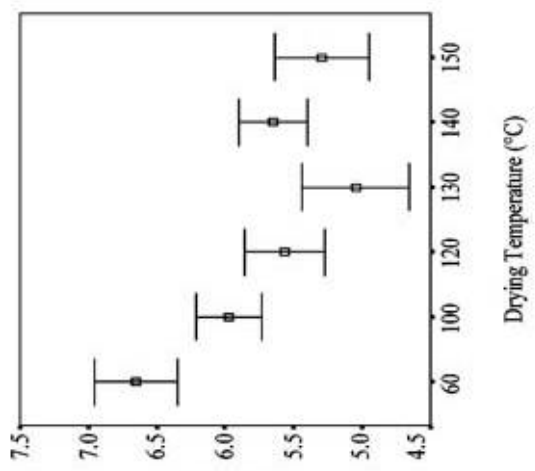

(\%) วพง

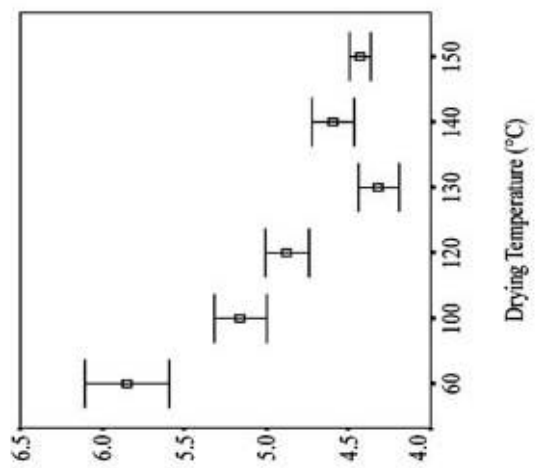

(\%) วพง
త

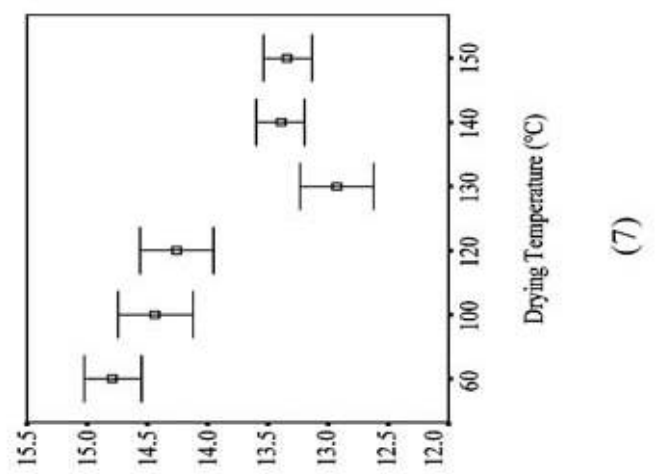

(\%) วพง

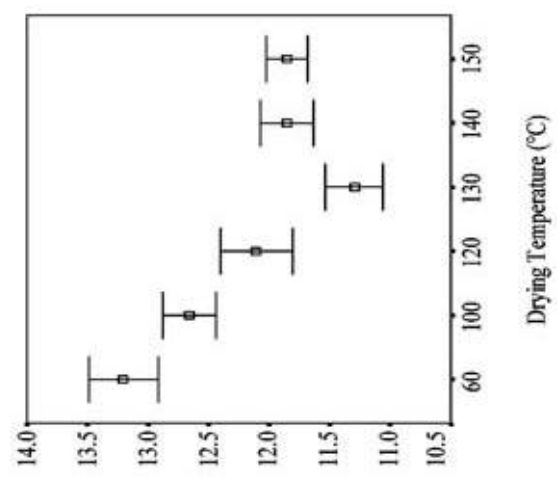

(\%) วพร

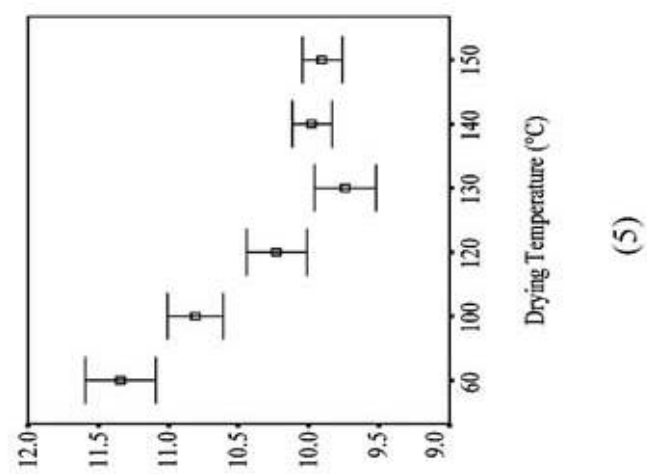

(\%) วพง

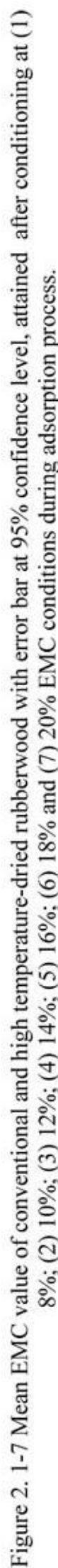




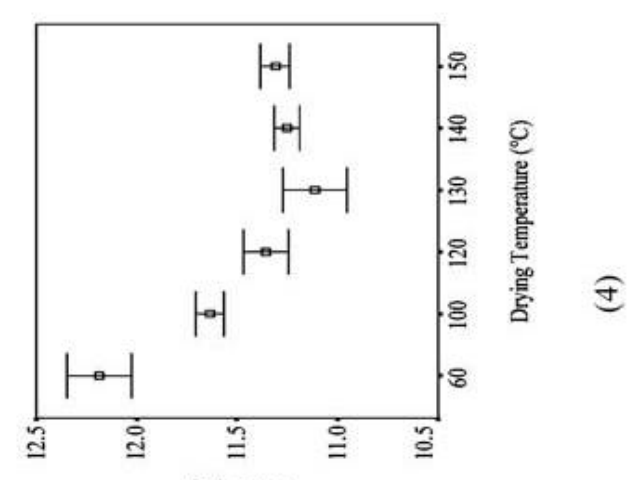

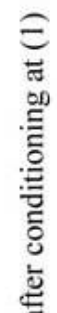

(\%) $ว \mathrm{wa}$

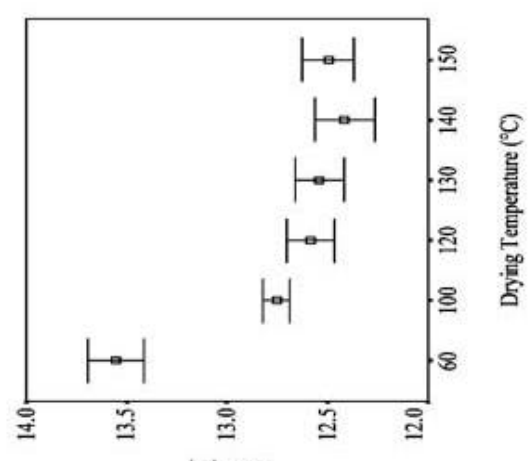

(\%) วพ3

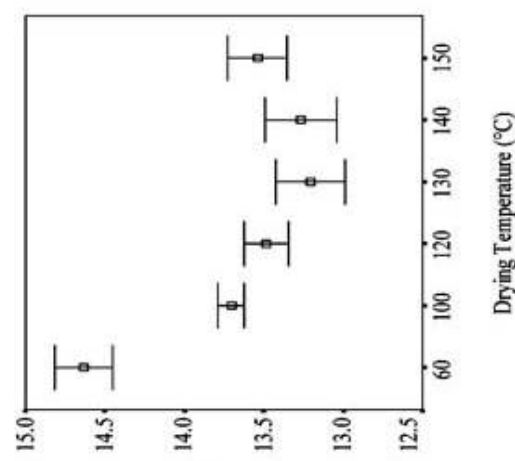

(\%) วพร

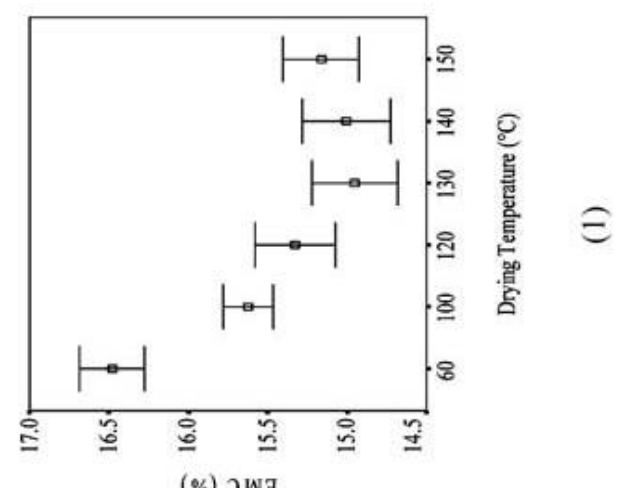

(\%) วพี
ลำ

สิ

(\%) วพง

(\%) $ว \mathrm{WJ}$
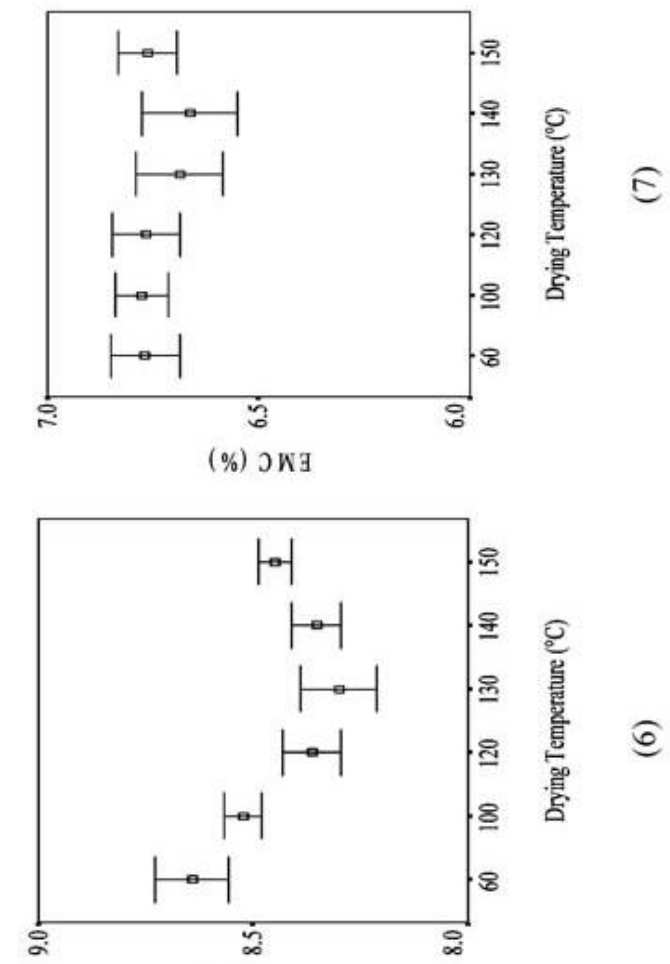

6

$E$

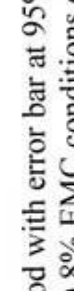

요

है

है

은

ปั่

륭

䒕

옹

些宁

हैं

플 


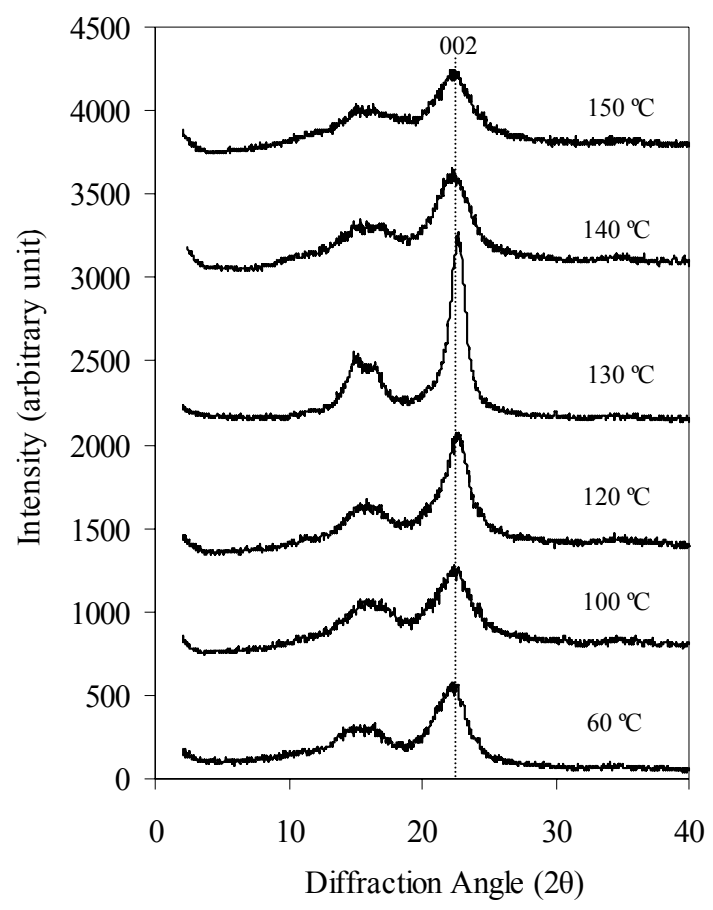

Figure 4. The X-ray diffractograms for the rubberwood samples dried at control conventional and high temperatures.

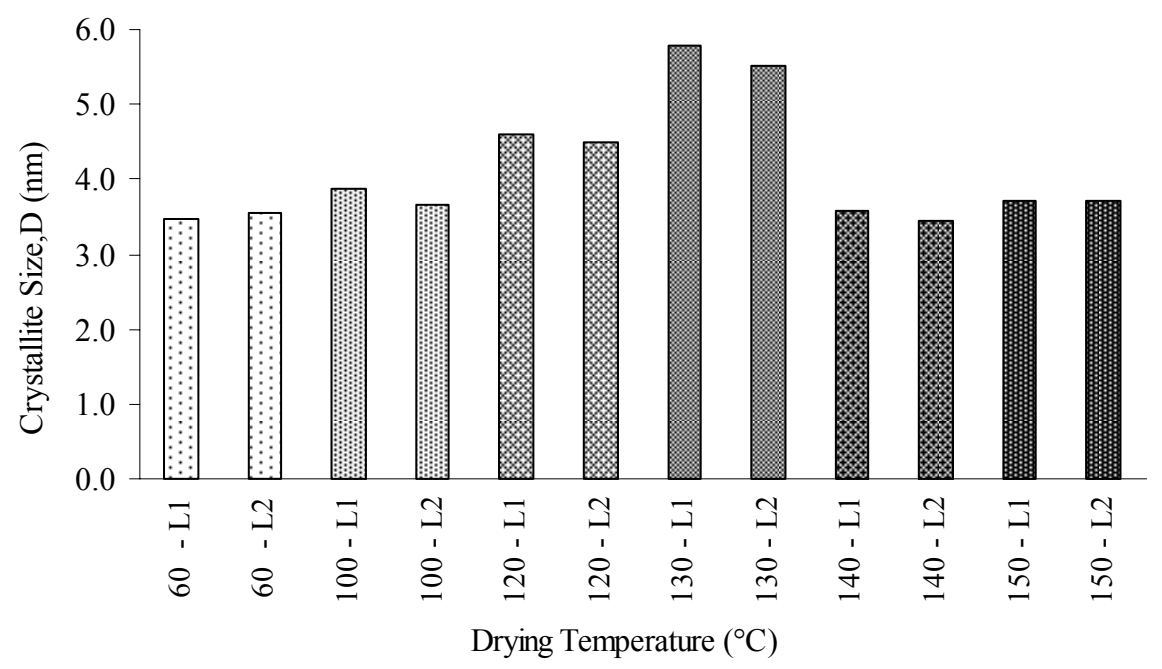

Figure 5. Mean crystallite size determined from the peaks of the 002 crystalline reflection of cellulose in rubberwood dried at control conventional and high temperatures. L1 and L2 are respectively the first and second layer from the wood surface. 


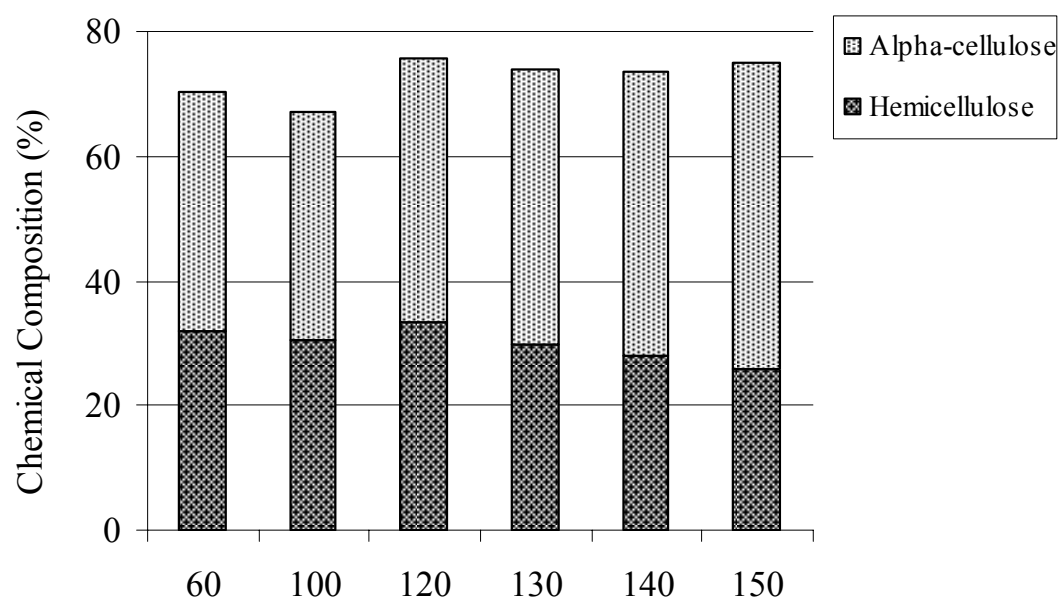

Drying Temperature $\left({ }^{\circ} \mathrm{C}\right)$

Figure 6. The holocellulose content of rubberwood dried at control conventional and high temperatures. 